Отримано: 21 липня 2021 року

Прорецензовано: 6 вересня 2021 року

Прийнято до друку: 20 вересня 2021 року

e-mail: le-12@ukr.net

DOI: $10.25264 / 2519-2558-2021-11(79)-148-152$
Sheverun N. V., Dzhurylo A. P. Phrasal verbs in the system of lexical units of modern English and their classificaton. Наукові записки Начіонального університету "Острозька академія»: серія «Філологія». Острог : Вид-во НаУОА, 2021. Вип. 11(79). С. 148-152.

$U D C: 811.111$

Nadiia Sheverun,

candidate of pedagogical sciences, associate professor,

Kyiv National University of Trade and Economics

Alina Dzhurylo,

candidate of pedagogical sciences, associate professor,

National Transport University

\title{
PHRASAL VERBS IN THE SYSTEM OF LEXICAL UNITS OF MODERN ENGLISH AND THEIR CLASSIFICATON
}

The article is devoted to the investigation of phrasal verbs in the system of lexical units of modern English and their classification. Focusing on the consideration of phrasal verbs as combinations of two full words and thus limiting the study to a combination of verb and adverb, it turns out that the semantic center of such combination is shifted under the influence of the adverb towards its meaning. Different classifications of phrasal verbs depending on the features that distinguish them from simple verbs are outlined.

It is found out, that the ability of the etymologically original unit of the postpositive to functionally reorient and become part of a phrasal verb is influenced by the frequency of use and the semantic volume of the adverb or preposition. It is distinguished, that phrasal verbs in English are very diverse both in their coherence or compatibility, and in the additional meanings they have in the text. A phrasal verb is the only semantic unit, that has its own specific features.

As a result of the research it was revealed that phrasal verbs have been found to help express thoughts more clearly and accurately than ordinary verbs and to convey those aspects of meaning that a simple verb is unable to convey. Phrasal verbs are necessary for free and correct understanding of English texts.

Key words: phrasal verbs, classifications of phrasal verbs, lexical units, modern English.

\section{Шеверун Надія Володимирівна,}

кандидат педагогічних наук, дочент,

Київський начіональний торговельно-економічний університет

Джсурило Аліна Петрівна,

кандидат педагогічних наук, доцент,

Національний транспортний університет

\section{ФРАЗОВІ ДІССЛОВА У СИСТЕМІ ЛЕКСИЧНИХ ОДИНИЦЬ СУЧАСНӦ̈ АНГЛІЙСЬКОЇ МОВИ ТА ЇХ КЛАСИФІКАЦІЯ}

Стаття присвячена дослідженню фразеологічних дієслів у системі лексичних одиниць сучасної англійської мови та їх класифікачії. Зосереджуючись на розгляді фразових дієслів як поєднань двох повнозначних слів і обмежуючи тим самим дослідження поєднанням дієслова та прислівника, виявлено, що семантичний центр такого поєднання змішується під впливом прислівника у бік його значення.

Окреслено різні класифікації фразеологічних дієслів залежно від ознак, щзо відрізняють їх від простих дієслів. 3 'ясовано, щзо на здатність етимологічно оригінальної одиниці постпозитиву функиіонально переорієнтуватись та стати частиною словосполучення впливає частота вживання та семантичний об'єм прислівника чи прийменника. Виявлено, шео фразові дієслова англійською мовою дуже різноманітні як за своєю зв язністю чи сумісністю, так $i$ за додатковим значенням, яке вони мають у тексті. Фразове дієслово - це єдина семантична одиниия, яка має свої специфічні особливості.

У результаті дослідження було виявлено, що фразеологічні дієслова допомагають висловлювати думки чіткіше і точніше, ніж звичайні дієслова, і передають ті аспекти значення, які не може передати просте дієслово. Фразові дієслова необхідні для вільного та правильного розуміння англійських текстів.

Ключові слова: фразові дієслова, класифікації фразових дієслів, лексичні одиниці, сучасна англійська мова.

Introduction. Historical documents show that phrasal verbs were used in Old English in the period from the V-XII centuries in the form of prefixal verbs (particle was added to the verb as a prefix). Postverbal particles also existed, but they only served to indicate direction, place, or orientation in space, as in "to grow up" (ward) or "to stand by" (place).

Numerous changes that took place in the English language during the Middle Ages helped to expand the number of phrasal verbs in the language. By the end of the 15th century (late Middle English) there were many phrasal verbs in various forms, from "understand" and "overtake" to "take up" and "write-off" [15].

Also, it should be noted that until the early period of modern English (early Modern English) - II half of XV - mid. XVII century - phrasal verbs sounded mostly only from the stage, in particular, in the works of W. Shakespeare, who widely used them in his plays. In fact, they were used in most dramas of the time due to the different shades of their meanings and the ability to form new idioms. However, in academic works and essays, in literature and in the official business style, priority was given to their one-word synonyms [16]. It should be noted that this rule is still followed in English.

Over the last 400 years phrasal verbs have become significantly entrenched in colloquial English [9, p. 67], as native speakers often use them in oral speech and writing. In most cases, there are verbs of Latin origin that describe a particular action, but Englishspeaking people prefer to use a phrasal verb to denote the same action. This perfectly illustrates the love of Americans for language simplification. For example, if you play chess with an American and he wins and in a few moves will give you chess and checkmate, 
you can say: I desist (I stop). However, he probably won't understand you. The word desist in English exists, but is almost never used. In this case, it is better to say: I give up. This phrasal verb expresses exactly the meaning you want to convey.

Due to the active use of phrasal verbs, their synonymous equivalents are either almost obsolete and few now remember them, or they have become more specific. Consider this in the following examples: give up - renounce; fall out-quarrel; pick up - improve; look up - search; carry on /go on - continue; pull away-leave; come back-return; break up-separate; hang around-to dawdle; switch on - to engage; to look forward - to wait.

Theoretical background. Phraseological verbs, which are active building blocks of speech, do not cease to attract the attention of researchers as complex structural and semantic formations, which, being simplified complex words, are a process and result of multi-stage transformations of these units. The investigation of phrasal verbs, their semantics, structure and use is relevant in the research of several foreign and domestic scholars, in particular, V. Ilchenko [7], T. Nikolayeva [10], R. Stasiuk [13], J. Povey [11], Yu. Zhluktenko [5] and others.

The purpose of this research is to investigate the peculiarities of phrasal verbs in the system of lexical units of modern English and their classification.

Results and discussion. The development of English does not stand still, and after studying the history of the origin and use of phrasal verbs, we came to the following conclusions: the transformation of English vocabulary in each of the main periods allows to improve the language as a whole and introduce new, more modern methods of learning English, as well as developing clearer characteristics for people to understand each other and facilitate communication.

The phenomenon of combining verbs with an adverb with two (sometimes three) component formations of a phraseological nature is a characteristic feature of modern English. Obviously, an important point for determining the approaches to the disclosure of the mechanism of formation of the meanings of phrasal verbs is directly related to determining the place of phrasal verbs in the system of lexical units of modern English. Considering them a word-forming morpheme, which has no independent syntactic function, it is necessary to consider this phenomenon at the morphological level (as complex words). Whereas the consideration of the second element as a sign word makes phrasal verbs the subject of syntax (as phrases). It should be noted that in domestic linguistics there is still no consensus on the grammatical status of the second component of the combinations under consideration, and the place of phrasal verbs in the system of lexical units of language.

The most significant contribution to the study of this phenomenon, of course, are the works of scientist I. Anichkov. He was the first in the 30s of XX century to identify the second element of such combinations as "English adverbial postpositions" [2, p. 221].

Adverbial postpositions are special category of postpositive adverbs (up, out, off, and others), consisting of units that have, in addition to generic features, the ability to join verbs,... to explain or clarify or supplement their meaning, [and] the following special (distinctive) features: when attaching postpositions to words to form constituent words (syntactically indivisible phrases) such as "to grow up" [2, p. 221]. The above-mentioned postpositive element to the verb is also called by the scientist B. Ilyish a postposition that "is on the border between a single word and a morpheme" [6, p. 74-72].

According to the scientist Yu. Zhluktenko, the second element of such combinations is a "postpositive appendix", and its connection with the verb is "a single, separately designed token, not a phrase" [5, p. 105].

The scientist M. Amosova calls different types of verb formations with postpositives verb-postpositive phraseology-combinations of a verb with a postpositive ("postposition"). Analyzing the role of the second element, M. Amosova comes to the conclusion that postpositives are "official words of a special kind" [1, p. 131].

Adhering to a similar point of view, the founder of English phraseology, Professor A. Kunin, in his classification of phraseological units on a structural basis considers such formations as single-vertex phraseological units [9, p. 79]. A. Kunin's use of the terms "single-vertex" and "double-vertex" phraseological units were borrowed from the scientist A. Smyrnytsky, who considers verbadverbial phraseological units, which are idiomatic combinations of verbs with so-called prepositional adverbs (give up, make out, ring up)... the most typical and characteristic for modern English single-vertex phraseological units" [12, p. 212]. In this regard, there is every reason to speak about the presence in modern English of "a syntactic pattern "verb + adverb" with the meaning of completeness of the process" [12, p. 214]. The second component of these verb-adverbial one-verb phraseological units "plays a subordinate role not only in lexical and semantic terms, but also in grammatical terms,... and does not serve to express the connection of this verb with other words in the sentence" [12, p. 214].

Focusing on the consideration of phrasal verbs as combinations of two full words and thus limiting the study to a combination of verb and adverb, it turns out that the semantic center of such combination is shifted under the influence of the adverb towards its meaning. The grammatical centre, of course, coincides with the first component of the phrase - the verb.

At present there are a large number of classifications of phrasal verbs (S. Grigoriev [4], I. Anichkov [2]), and it depends on the features that distinguish them from simple verbs. In addition, there are always verbs that allow different interpretations. Therefore, the classification of phrasal verbs can be called quite conditional.

According to the classification, which is based on the number of postpositives in the phrasal verb, their indivisibility and the presence or absence of the adverb (transitive / intransitive verbs), there are four types of phrasal verbs:

1. Phrasal verbs with two postpositives. Most of these verbs require an adverb, which can be placed only after the phrasal verb, without breaking it. That is, these phrasal verbs are indivisible: I'm looking forward to my holidays. You must face up to reality!

2. Phrasal verbs with one postpositive: transitive and indivisible. These verbs require an adverb that stands after the postpositive, the adverb cannot break the phrasal verb: I love coffee. I can't do without it in the morning! I'm counting on you to help me.

3. Phrasal verbs with one postpositive: transitive and divisible. These verbs require an adverb that can stand after a postpositive or between a verb and a participle (thus a phrasal verb is divisible): We brought up this child. We brought her up. Jill asked me not to give her secret away.

4. Phrasal verbs with one postpositive: intransitive. These verbs are used without the adverb: Charles and Emily have fallen out again. You always show off at parties.

Depending on the degree of semantic unity of the components in the composition of the phrasal verb, there are two main types of phrasal verbs, namely: 
1. Phrasal verbs that are close to free combinations. They are characterized by a low level of semantic unity, namely the meaning of the phrasal verb can be easily deduced from the meanings of its components (to call back, to look for and others). Such phrasal verbs are usually partially motivated (postpositive component loses the specificity of its spatial meaning and retains the connection with the original meaning of the free adverb).

2. Phrasal verbs belonging to the category of phraseological units. They are characterized by the greatest degree of semantic unity of components: the meaning of the combination can not be derived from the meaning of the components that are part of it (bring up = educate, give up = stop doing smth and others). The semantic relations between the constituent parts of English phrasal verbs are extremely diverse.

Considering the syntactically indivisible combinations of verbs and postpositives in terms of postpositive meanings, we can distinguish the following types of phrasal verbs:

1. verb-adverb complexes in which the postpositive has its primary concrete-spatial meaning. For example: come out, take away, walk in, run out, step across;

2. combinations in which the meaning of the verb has a clear figurative (metaphorical) character, while the second component retains the inherent spatial meaning of the adverb: let a person down $=$ fail him; bring out $=$ expose; pull through $=$ recover;

3. constructions in which the main semantic changes undergo a postpositive element, which acquires a bright aspectual content. Among the aspectual shades are the following:

- expression of the beginning of the action (cry out),

- expression of continuation on action (walk on),

- expression of completion, end of action (burn away),

- designation of complete exhaustion of action (tire out),

- expression of action intensification (work away),

- expression of repetition of action (read over / again);

4. the meaning of phrasal verbs is based on the idiomatization of both parts, the motivation of which is preserved: come about, come out, give away;

5. phrasal verbs, characterized by the maximum degree of idiomatization of their components: give up (throw), take in (deceive), put up with (tolerate, reconcile).

The typology of phrasal verbs is very different according to the meaning of a phrasal verb. This issue is covered in the works of such scholars as I. Anichkov [2], R. Courtney [8], J. Povey [11] and other linguists and scientists.

Scientist R. Courtney distinguishes several types of phrasal verbs:

1. Idiomatic expressions (verb + adverb / preposition) like give up.

2. Verbs that are used only with a certain preposition or adverb, such as rely on, agree to, depend on.

3. Combinations of verbs + adverbs that mean almost the same as the corresponding simple verb, for example: hurry up (= hurry), eat up (=eat). In such combinations, the adverb only emphasizes the meaning of the verb or adds a shade of completeness or duration to the action, expressed by the verb.

4. Phrasal verbs that always take "it" as an adjunct: jump to it (= act as quickly and energetically), slug it out (= fight till complete victory).

5. Reverse phrasal verbs followed by the application myself, yourself, himself, and others is always used. For example: pride yourself on, lend itself to, avail yourself of [8, p. 57-59]. Phrasal verbs should not be confused with regular expressions such as step out of line, eat your heart out and others, which are called phraseological units or idioms.

Considering syntactically indivisible combinations of verbs and postpositive in terms of postpositive meanings, the scientist I. Anichkov divides the following combinations into five categories:

- combinations to which the postpositive has its primary concrete-spatial meaning, For example: go in, come out, take away, bring back;

- a combination in which the postpositive has an abstract derivative meaning, the connection of which with the primary is felt. For example: let a person down = fail him; come in = find a place; bring out = expose; pull through = recover; pick up = acquire;

- combinations in which the postpositive only emphasizes or reinforces the meaning of the verb. For example: fall down, rise up, turn over, circle round;

- combinations of meanings that do not consist of the meanings of verbs and postpositions, do not feel as arising from them, but are semantically inseparable. For example: come about = happen; fall out = quarrel; give up = abandon; drop off = fall asleep; take in = deceive;

- combinations to which the postpositive gives a lexical-specific shade.

In the last category the postpositive gives a shade:

a) perfect: eat up = eat the hole; carry out = execute;

b) terminative, which means not the incompleteness of the action, but the termination of the unfinished action: leave off work; give up an attempt;

c) inactive or initial: strike up a tune, light up = begin smoking; break out = to start suddenly (of violent events).

d) durable or long: go on, talk away, struggle along;

e) interactive or repetitive. Such postpositives as again, anew, afresh, sometimes back and over joining the verbs, form a combination with the meaning of repetition: write again, write anew, write afresh.... [2, p. 243-246].

Phrasal verbs in English are very diverse both in their coherence and in the additional meanings they have or which they acquire in the text. Phrasal verbs can express the nature of the action, the transition from one state to another, the motivation for action and so on, but in all cases the action is invariably characterized by the meaning, that the verb itself has.

Therefore, the scientist I. Anichkov singled out a numerous and diverse group of phrasal verbs that express movement and at the same time characterize it. Verbs in this group often express not just movement, but the transition from one place to another. 
Therefore, most of them are used with a postpositive that indicates the direction of movement (into, out, up, to). For example: stand up - to rise; go into - to enter; jump into - to jump, to slip.

Several cases should be noted when the phrasal verb expresses the termination or, conversely, the beginning of the action. For example: get over - to finish, to deal with something; jump down - to jump lower, to jump below smth; run out - finish the race; throw off, get off - to start (something). A very large group consists of phrasal verbs, that express the transition of an object from one state to another or its movement. In essence, verbs that deny the transition from motion to immobility or the beginning of motion can be assigned to this group or considered as an intermediate link. In general, the boundaries between individual groups of phrasal verbs are very volatile in lexical terms, so they are not easy to define. For example: 1) move in = to take possession of a new place to live; move towards -1) to go in the direction of (something or someone), 2) to change one's opinion in the direction of; move off = to start a journey; leave.

The third group includes phrasal verbs with the semantic component "no change in the position of the object." For example: stay behind $($ keep behind $)=$ to remain at a distance behind something or someone; stay down = to remain at a lower level; remain ahead = to stay in a forward or leading position.

The next group of verb meanings is dominated by the component of "image of movement". For example: walk away from = to leave (something or someone) on foot; walk about / around = to walk in a place without direction; spin along = to move forward easily and quite quickly with a rolling movement; frighten away / off = to make (somebody) leave through fear [2, p. 248].

To correctly understand and use phrasal verbs, you need to divide them into groups according to the classification:

1) whether the sample is transient or non-transient;

2) whether it consists of one or two postpositives;

3) whether the postpositive has an adverbial or prepositional character.

Scientist Jane Povey divided phrasal verbs into six types according to this classification:

a) intransitive verb with an adverbial postpositive: The alarm clock went off at 7 o'clock (Alarm clock rang at seven o'clock).

b) intransitive verb with a prepositional postpositive: I came across that word in a newspaper (I understood that word in a newspaper).

c) intransitive verb with adverbial and prepositional postpositive: She put up with the interruptions cheerfully (She readily withstood obstacles).

d) a transitive verb with an adverbial postpositive: He looked up the word in the dictionary (He found the word in the dictionary).

This type is divided into two small subtypes:

- the postpositive always precedes the subject, unless the latter is a pronoun: I wish you'd give up smoking (give it up) (I would like you to quit smoking).

- the postpositive always follows the subject: The lecturer got his point across very well (The lecturer very clearly conveyed his opinion).

e) transitive verb with a prepositional postpositive: The instructor put my sister off driving (The instructor distract my sister from driving).

e) transitive verb with adverbial and prepositional postpositive: You shouldn't take your resentment out on the children (You shouldn't take anger on children) [11, p. 112].

The most complete is the structural-semantic classification of phraseological verbs, proposed by the scientist Yu. Zhluktenko [5, p. 105-113], according to which it is necessary to distinguish:

1. Verbs with postpositive morphemes that retain their original local meaning: come in, go out, go down, lay off, sweep away, and others.

2. Verbs with postpositive morphemes that have a figurative meaning: boil down (reduce, reduce to something), take off (drop the price), take up (fill time), get along (succeed), speak away (talk), and others.

3. Verbs with postpositive morphemes that intensify the verb or give its meaning to the seventh completeness, for example: eat up, rise up, swallow up, open up, and others.

4. Verbs, the meaning of which cannot be considered as the sum of the meanings of the components: give in (give up), give up (throw), come about (happen) [5, p. 105-113].

The modeling of the formations of groups 3 and 4 allows to refer them to phraseologized formations. Phraseological verbs are often part of many phraseological units: Blow off - blow off steam (infml to give expression to anger, excitement); Cut off - cut someone off without a penny (to stop a supply of money); Get on - get on one's skates on (infml to act quickly); Get up - get up one's dander / monkey up (infml to become angry); Give up - give somebody up as a bad job, give up the ghost; Take in - take a hand in (to be partly the cause of or have an effect on (something)); Turn up - turn up tramps (not infml to be surprisingly successful, helpful, or lucky).

Scientist R. Side [14, p. 144-152] argues that new phraseological verbs are constantly appearing in slang, such as boogie down, and in scientific and technical fields, such as spin down. In his opinion, they are formed not by chance. The particle, being an integral part of phraseological verbs, is sometimes no less semantically significant than the verb. This leads to the processes of development of both the ambiguity of individual verb lexical units and the semantic derivation of phraseological verbs as a whole.

Depending on the morphological nature of the postposition, all phrasal verbs can be divided into the following three groups:

1. Verb + preposition: "to pick up" - to call in, pick up, get (information), lift (mood); "to carry out" - to perform; "to set off" - to go (on the road), to cause (action).

2. Verb + adverb: "to come across" - to meet by chance; "to break down" - to be upset; "to hang around" - to wander, to be idle; "to tell against" - to disclose, certify, respond.

3. Verb + preposition + adverb: to go along with" - to accompany, obey, agree; "to come down with" - to take, accept, conclude, acquire; "to get back at" - to take revenge, to repay.

So, phrasal verbs are idiomatic verb constructions that occupy a special status in the system of phraseology of the English language. Like ordinary verbs, phrasal verbs can be intransitive and transitive. Some English phrasal verbs are transitive, such as "get 
over", "hand in", "pick out"; others are intransitive, such as "get up", "break down", "look out"; while some others are both transient and non-transient, such as "call up", "give up", "hang up".

Transitive phrasal verbs are divided into two categories: separate or separable and inseparable, depending on the location of the direct application in relation to the preposition. Inseparable include all intransitive phrasal verbs and some transitive (run into, get up, break down, and others).

If the verb is divided, the adverb can stand immediately after the phrasal verb, or between the verb and the postpositive (to turn down my offer = to turn my offer down - to reject my sentence). I would like you to shut it down! "I want you to close them!" It is raining outside. Put on your jacket when you go shopping. (Put your jacket on). - It's raining outside. When you go to the store, put on a jacket.

So, the ability of the etymologically original unit of the postpositive to functionally reorient and become part of a phrasal verb is influenced by the frequency of use and the semantic volume of the adverb or preposition.

Conclusions. Thus, phrasal verbs in English are very diverse both in their coherence or compatibility, and in the additional meanings they have in the text. A phrasal verb is the only semantic unity that has its own specific features. The correct use of phrasal verbs makes speech more natural, and the correct understanding of phrasal verbs and their reproduction in the language of translation is a sign of a high level of mastery of a foreign language. Since many scholars have proposed their definitions and features by which they distinguish phrasal verbs, there are many classifications of phrasal verbs based on one or another criterion - it can be the degree of semantic unity of components, divisibility or indivisibility of phrasal verbs, presence or absence of adverbs and others.

\section{References:}

1. Амосова Н. Н. Основы английской фразеологии. Ленинград : Изд-во ЛГУ, 1963. 207 с.

2. Аничков И. Е. Английские адвербиальные послелоги : дисс. ... докт. филол. наук : 10.02.04. М., 1947. 536 с.

3. Воробйова О. С. Полісемія англійських фразових дієслів. Молодий вчений. № 5.1 (69.1). 2019. С. 59-62.

4. Григорьев С. В. Фразовые глаголы: учебно-справочное пособие. Санкт-Петербург : КАРО, 2003.272 с.

5. Жлуктенко Ю. А. О так называемых «сложных глаголах» типа stand up в современном английском языке. Bonросы языкознания. Москва : Наука, 1984. № 5. С. 105-113.

6. Ильиш Б. А. Современный английский язык. Теоретический курс. 2-е изд. Москва : Изд-во лит-ры на иностр. яз., 1948.347 с.

7. Ильченко В. В. Фразовые глаголы в английском языке. М., 2015. 240 с.

8. Кортни Р. Английские фразовые глаголы. Москва, 2001. 767 с.

9. Кунин А. В. Английская фразеология. Москва, 1990. 276 с.

10. Ніколаєва Т. М. Види фразових дієслів в англійській мові (теорія та практика). Закарпатські філологічні студії. Вип. 3. Том 2. С. $149-154$.

11. Поуви Д. Говорите правильно по-английски [Текст]. Москва : Высшая школа, 1984. 268 с.

12. Смирницкий А. И. Лексикология английского языка. Москва : Изд-во лит-ры на иностр. языках, 1956.259 с.

13. Стасюк Р. Фразові дієслова англійської мови. Київ : Арій, 2017. 96 с.

14. Side Richard. Phrasal verbs: Sorting them out. ELT Journal. April, 1990. P. 144-152.

The development of phrasal verbs in British English from 1650 to 1990: A corpus-based study by Paula Rodríguez Puente. URL : https:// www.englishexperts.com.br/the-development-of-phrasal-verbs.

The Origin of the Phrasal Verb. URL : https://www.englishexperts.com.br/the-origin-of-the-phrasal-verb. 